\title{
AIR POLLUTION AND RESPIRATORY HEALTH IN AFRICA: A REVIEW
}

\author{
M.O. TANIMOWO
}

\begin{abstract}
Objective: To bring into focus the existence of respiratory hazards due to air pollution as a result of industrialisation, tobacco smoking (personal pollution), domestic pollution and vehicular fuel combustion on the African continent; and to stimulate health workers, and the various governments in Africa, to devote more attention to the subject of air pollution by engaging in and encouraging multidisciplinary research so that appropriate and effective control measures can be put in place.

Data sources: Medline literature search through internet using the keywords: air pollution, cigarette smoking, domestic pollution, respiratory morbidity, Africa. The author's contributions to the subject of air pollution and respiratory morbidity are included.

Study selection: Relevant studies or articles from eastern, western, northern, southern and central parts of Africa are included in the review.

Data extraction: From individual study or article.

Data synthesis: Evidence of respiratory hazards sequel to the four main sources of air pollution in each part of Africa, are synchronised under the headings: introduction, respiratory impairment and the future.

Conclusions: Respiratory impairment from the four main sources of air pollution is a major but highly neglected problem on the African continent. There is need for concerted efforts on the part of African governments, health administrators and health workers to ensure that necessary attention is given to multidisciplinary research on the subject so that meaningful control measures can be formulated, thereby ensuring clean air for the people to breathe.
\end{abstract}

\section{INTRODUCTION}

Air pollution is the introduction into the air of any substance different from any of its natural constituents. It is therefore a man- made problem from four main sources, namely, industrialisation, tobacco smoking, domestic cooking, and vehicular or machinery fuel combustion.

All over Africa, studies have shown that air pollution from all the four sources adversely affects people's respiratory health(1-9). Despite this realisation, little or no attention has been given to the subject thereby making control of this man-made nuisance difficult, or in some places even apparently impossible. But a man-made problem needs another man to put it under control.

Air pollution is either due to gases (carbon monoxide, nitrogen dioxide, sulphur dioxide, benzene and ozone) or particulates (dust). These, singly or in combination cause respiratory impairment if inhaled at adequate concentrations and over a long enough period of time $(10,11)$.

The World Health Organisation has always been interested in the subject of air pollution, and one of its expert committees on "Atmospheric Pollution" approved the basic conclusions of a WHO Inter-Regional Symposium on criteria for "Air Quality" and methods of measurement and suggested as guides to air quality, four categories of concentrations and exposure times, and corresponding effects(11).

Level I: Concentrations and exposure times at or below which, according to present knowledge, neither direct nor indirect effects (including alteration of reflexes or of adaptive or protective reactions) have been observed.

Level II: Concentrations and exposure times at and above which there is likely to be irritation of the sensory organs, harmful effects on vegetation, visibility reduction, or other adverse effects on the environment.

Level III: Concentrations and exposure times at and above which there is likely to be impairment of vital physiological functions or changes that may lead to chronic diseases or shortening of life.

Level IV: Concentrations and exposure times at and above which there is likely to be acute illness or death in susceptible groups of the population. Level I is of primary practical interest for the control of atmospheric pollution, since no concentrations above that level should be permitted. Although this committee did not specify the actual concentrations and exposure times for these four levels, another WHO study group(10) has recommended the following safety margins for nitrogen dioxide and sulphur dioxide shown in Tables l(a) and (b), respectively. 
Table 1 (a)

For nitrogen dioxide

\begin{tabular}{lll} 
Exposure time & Concentration \\
\hline a. & Short $(15$ minutes $)$ & $1 \mathrm{ppm}$ or $1.8 \mathrm{mg}^{3} \mathrm{~m}^{3}$ \\
b. & Long term ( 8 hours $)$ & $0.5 \mathrm{ppm}$ or $0.9 \mathrm{mg} / \mathrm{m}^{3}$ \\
\hline
\end{tabular}

Table 1 (b)

For sulphur dioxide

Exposure time

a. Short ( 15 minutes)

b. Long term ( 8 hours)
Concentration

$3.9 \mathrm{mg} / \mathrm{m}^{3}$

$1.3 \mathrm{mg} / \mathrm{m}^{3}$

Table 2

Air pollution standards - limits of concentrations permitted

\begin{tabular}{|c|c|}
\hline Pollutant & $\begin{array}{l}\text { weight of pollutants per } \\
\text { cubic meter of air }\end{array}$ \\
\hline Carbon monoxide & $10 \mathrm{mg}$ maximum, 8-hour concentration \\
\hline Sulphur Oxides & $\begin{array}{l}80 \text { micrograms annual mean } \\
365 \text { micrograms maximum } \\
24 \text { - hour concentration }\end{array}$ \\
\hline Hydrocarbon compounds & $\begin{array}{l}125 \text { micrograms maximum } \\
3 \text { - hour concentration }\end{array}$ \\
\hline $\begin{array}{l}\text { Nitrogen oxides } \\
(\mathrm{NO}, \mathrm{NO} 2 \text { ) }\end{array}$ & $\begin{array}{l}100 \text { micrograms annual mean } \\
250 \text { micrograms maximum } \\
\text { 24-hour concentration }\end{array}$ \\
\hline $\begin{array}{l}\text { Petrochemical oxidants } \\
\text { (e.g. ozone) }\end{array}$ & $\begin{array}{l}125 \text { micrograms maximum } \\
1 \text { - hour concentration }\end{array}$ \\
\hline Particulates & $\begin{array}{l}75 \text { micrograms annual mean } \\
260 \text { micrograms maximum } \\
\text { 24-hour concentration }\end{array}$ \\
\hline
\end{tabular}

Also the allowable limits of various air pollutants in the United States of America(12) are shown in Table 2.

Air pollution causes pathological damage in three different parts of the lung, namely, the major bronchi, the terminal bronchioles, and the alveoli (13).

Major bronchi: With acute exposure, there may be reversible bronchospasm with considerable individual variation. The longer term effects are more important and they result from particles with size 2.0-50.0 $\mu$ and/or gas exposure, such as, sulphur dioxide, nitrogen dioxide and ozone. These effects consist of: (i) paralysis of cilia; (ii) hyper secretion of bronchial mucous glands; (iii) mucous gland hypertrophy and extension into smaller air ways, a phenomenon documented by Reid to occur as a result of exposure of rats to high concentrations of sulphur dioxide(14); (iv) increased susceptibility to infections as a consequence of the above factors and; (v) these factors lead to a chronic productive cough in the long term.

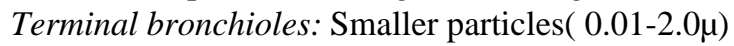
will penetrate and be deposited in this region, and there could be potentiation of effects if gases and particles are inhaled concurrently as in cigarette smoke. Most of the sulphur dioxide that is breathed in is stopped in the nose, and soluble gases such as oxides of nitrogen are similarly diminished if breathed in the gas form. Combined with particles, these gases get further down the lung and have 
greater effect in lower concentration. There are also some experimental data and some human data indicating that acute exposure to high concentrations of oxides of nitrogen characteristically produces pulmonary oedema and fibrosing bronchiolitis rather than chronic bronchitis or bronchiectasis(15). These gas exposures produce the following effects in the terminal bronchioles: (i) loss of normal defences; (ii) adverse effect on surfactant, which has something to do with keeping these small airways patent; (ii) goblet cell metaplasia; (iv) inflammation and obliteration and; (v) premature closure of airways, which is what has been demonstrated with increased closing volume in cigarette smokers.

Alveoli: Particles of range order $0.01-0.05 \mu$ are particularly likely to get to this region and in modern city air, there are plenty of particles in this size range. It is difficult to calculate how much of a gas such as ozone actually reaches the alveolar level because it is so reactive to surfaces, and it is possible that much of it has disappeared before reaching the alveolar wall. Some gases, such as, sulphur dioxide may be absorbed in the nose and later removed through the alveoli and then exert their effect not by having them delivered to the alveoli through the bronchial tree but by rediffusion out from the blood into alveolar gas. If both particulate and gaseous pollution are present there is potentiation of effects, and the major consequences of each of these is an increase in cells and macrophages in the lung(13). There is ample evidence that this is the primary response to most of these challenges, and an increased aggregation of macrophages and leucocytes occurs quite quickly in response to most of them(16). The presence of these cells will enhance the release of proteolytic enzymes, causing alveolar destruction in individuals with inherited deficiency of serum antitrypsin, with the subsequent possibility of developing emphysema(13).

Respiratory impairment: Rural and urban areas of Africa where industries are situated have been shown to have a high prevalence of respiratory symptoms and reduced lung function. For example, this author demonstrated a high frequency of occurrence of cough alone, cough with sputum, morning phlegm, nasal catarrh, chest pain and reduced lung function among the residents of Bacita, Kwara State, Nigeria sequel to their exposure to air pollution from the process of sugar production(1) and Fatusi et al(17) also drew similar conclusions from sawmill workers in southwest Nigeria. In eastern Africa, Mengesha et al(2) studying the respiratory effects of dust in different sections of yarn, cement and cigarette factories found a higher prevalence of chronic cough, chronic bronchitis and bronchial asthma among the workers than the controls. Results of the studies from southern Africa and northern Africa $(3,4,18-22)$ are similar to those mentioned above from West and eastern Africa. Rees et al (18) found an uncontrolled dust hazard in all the nine foundries surveyed in South Africa in a period of nine years. The prevalence of silicosis among foundry workers was found to increase with the duration of service, and the results from their study epitomises the neglect of occupational health by the foundry industry.

The smoking of tobacco and its products has been recognised as a cause of respiratory impairment in Africans for a long time. In the 1980s, the World Health Organisation tried to focus on this subject(23), but more recent studies have shown that cigarette smoking is actually on the increase on the continent(24-25) with the attendant increase in respiratory morbidity. A recent study from West Africa showed that the ambient concentrations of carboxyhaemoglobin is high in Lagos city dwellers and this is further aggravated by cigarette smoking. Cigarette smoking has been associated with lung cancer among Nigerians just as in other parts of Africa(26). Studies from South Africa also demonstrated the continued deterioration in respiratory health from cigarette smoking, whether the smoking is active or passive(27-29). Theron et al (6), also from South Africa, have shown that cigarette smoking causes increased numbers and pro-oxidative activity of circulating neutrophils and monocytes, decreased plasma concentrations of vitamin $\mathrm{C}$, and pulmonary dysfunction. Furthermore, cigarette smoking has been blamed for the increased incidence of lung cancer in southern and eastern Africa. About five patients were admitted with lung cancer to the Kenyatta National Hospital in Nairobi each year in the 1960 s, but today in the 1990 s over 40 are admitted(30).

In most homes in Africa, cooking with firewood, charcoal or kerosene is the rule rather than the exception. Femi-Pearse et al (31) found an association between the use of firewood for cooking and early morning expectoration and persistent phlegm. They found that $72 \%$ of their respondents used wood for cooking and they regarded this as the greatest source of atmospheric pollution in Nigeria. Sofoluwe(32), working in Lagos, Nigeria visited the homes of 98 children suffering from bronchiolitis and pneumonia and found that these patients had been exposed to high concentrations of carbon monoxide, nitrogen dioxide, sulphur dioxide and bezene. Tanimowo(33) demonstrated the addictive effects of cigarette smoking, smoke from wood-fire and kerosene stove on the development of respiratory impairment in the population exposed to air pollution from sugar production in Nigeria. Domestic air pollution has also been found to contribute to the development of asthma in Kenyan school children(7), and acute respiratory infections in Ugandan children(34). Mozambican women who cook with firewood have been shown by Ellegard(35) to have a high prevalence of respiratory symptoms, especially cough. In South Africa, more than 20 million people are said to rely on traditional (wood) and transitional (coal and kerosene) fuels to fulfil their basic energy needs, that is, cooking and space heating, and studies have confirmed their exposure to high concentrations of air pollutants(36) with the attendant respiratory impairment. The levels of exposure to particulates was found to be in the range of 294 to 2304 micrograms $/ \mathrm{m}^{3}$ with the average 12 - hour exposure worse in winter than in summer. 
There are studies in Africa to prove that the people are exposed to air pollution from vehicular and machinery fuel combustion(8). A study by Ogunsola et al from Nigeria(37) has shown that traffic wardens have a higher blood lead levels than controls and they also have reduced spirometric measurements than controls. In South Africa, Nriagu et al (9) have also demonstrated higher average atmospheric concentrations of lead in industrial and commercial areas of Durban than in the residential areas.

Future: For Africans to be free of respiratory morbidity sequel to air pollution, future devotion and emphasis has to be given to control measures. At the moment, the presence of the problem is already established, but no solution. Hence the way forward is to focus research efforts and governmental plans on prevention. The various governments in Africa need concerted political will to deal with the problem of air pollution on the continent. This is lacking at the moment in most African countries.

This political will would ensure the much needed funding for air pollution research, the human resources and the mandatory co-operation from industries that generate air pollutants.

While it is a fact that Africa is still beset with diseases from infections and malnutrition and colossal sums of money are needed to cope with these, no major health sector reform should be undertaken on the continent without including control of air pollution(38). Each Ministry of Health should have an effective Air Pollution Control Unit(8). The World Health Organisation should continue to ensure regional and inter-regional co-operation on air pollution control $(10,39,40)$, and promote research on all aspects of the subject, giving particular attention to epidemiological studies, measurement of levels of air quality, and prevention. A multi-disciplinary approach to research is essential for any effective control programme of air pollution. Specialists from medicine, natural sciences, metereology, engineering, city planning, business and law must be well-integrated to combat this menace.

At the moment, African medical students and resident doctors are not adequately exposed to the subject of air pollution and its consequences on respiratory health. Medical education curricula on the continent and textbooks of medicine should therefore give the subject the much needed attention so that the interest of these potential future researchers can be aroused. Such efforts are already being made in the United States of America(41). Legislation has a clear role to play in the control of air pollution in Africa. Laws can be passed and enforced so that industries generating air pollutants are made to control the pollution at the source level while workers can be forced to wear protective masks $(17,42)$.

Cigarette smoking can be banned especially among the youth in Africa. This effort is already being made by some African governments(43). Manufacturers and advertisers of tobacco and its products, can be made to pay heavy taxes, thereby making the retail price exorbitant.

To control domestic pollution from cooking, modern technology, such as, solar energy may have to be exploited.
This should be so adapted to be effective and cheap for the African situation.

Vehicular or machinery fuel combustion causing air pollution can be controlled by the use of lead -free gasoline in all African countries (as is done in some countries already)(9) and improvement of refinery techniques of crude petroleum.

Vigorous health education campaigns have to be commenced to alert the African peoples on the attendant respiratory consequences of air pollution from all sources. This will ensure that the people co-operate with any control measures taken by the government or health authorities to make cleaner the air they breathe.

\section{REFERENCES}

1. Tanimowo, M.O. The respiratory effects of industrial pollution in Bacita, Kwara State; Nig. Nig. Med. Prac. 1995; 29:8-10.

2. Mengesha, Y.A. and Bekele, A. Relative chronic effects of different occupational dusts on respiratory indices and health of workers in three Ethiopian factories.Amer. J. Ind. Med. 1998; 34:373-80.

3. Hsairi, M., Maalej, M. Achour, N. et al. Respiratory effects of air pollution in two popular districts of the Greater Tunis Metropolitan Area. A study in school environment. Tunis Med. 1996; 74:119-24.

4. Shamssain, M.H. and Shamsian, N. Respiratory symptoms and pulmonary function in a group of women weavers in South Africa. Ann. Hum. Biol. 1997; 24:299-306.

5. Uko, G.P., Gbadebo, J.A. and Banjoko, S.O. Carboxyhaemoglobin levels in some Lagos dwellers- a pilot study. West Afr. J. Med. 1998; 17:202-5.

6. Theron, A.J., Richards, G.A. Myer, A.S. et al. Investigation of relative contributions of cigarette smoking and mineral dust exposure to activation of circulating phagocytes, alterations in plasma concentrations of vitamin $\mathrm{C}$, vitamin $\mathrm{E}$, and beta-carotene, and pulmonary dysfunction in South African gold miners. Occ. Environ. Med. 1994; 51:564-7

7. Mohamed, N., Ng'ang'a, L. and Odhiambo, J. et al. Home environment and asthma in Kenyan school children: a case -control study. Thorax 1995; 50: 74-8

8. Tanimowo, M.O. Air pollution and respiratory morbiditythe situation in developing countries. Zambian J. Med. Hlth Sci. 1998; 2:14-16.

9. Nriagu, J., Jinabhai, C., Naidoo. R., et al. Atmospheric lead pollution in Kwa Zulu/Natal, South Africa. Sci. Total Environ. 1996; 191: 69-76.

10. World Health Organisation. Recommended health-based occupational exposure limits for respiratory irritants. World Health Organisation. Tech. Rep. Ser. 1984, No.707.

11. World Health Organisation. Who Expert Committee on Atmospheric Pollutants. Wld Hlth Org. Tech. Rep. Ser. 1964, No. 271

12. Strahler, A.N. and Strahler, A.H. In: Introduction to Environmental Science. Hamitton Publishing Co. New York, USA, 1974.

13. Bates, D.V. Air pollutants and human lung. Amer. Rev. Resp. Dis. 1972; 105:1-13. 
14. Reid, L. Evaluation of model system for study of airway epithelium, cilia, and mucus. Arch. Intern. Med. 1970; 126: $428-434$.

15. Becklake, M.R., Goldman, H.I., Bosman, A.R. and Freed, C.C. The long term effects of exposure to nitrous fumes. Amer. Rev. Tuberc. 1957; 76:398.

16. Erikson, S. Studies in serum alpha-l anti-trypsin deficiency. Acta Med. Scand. 1965; 177 supp. 432: p.1.

17. Fatusi, A., Erhabor, G. Occupational health status of sawmill workers in Nigeria. J. roy. Soc. Hlth 1996; 116:232-6.

18. Rees, D. and Weiner, R. Dust and pneumoconiosis in the South African foundry industry. S. Afr. Med. J. 1994; 84:851-5.

19. Hnizdo, E. Sluis-Cremer, G.K., Baskind, E. and Murray, J. Emphysema and air way obstruction in non-smoking South African gold miners with long exposure to silica dust. Occup. Environ. Med. 1994; 51: 557-63.

20. Steen, T.W., Gyi, K.M., White, N.W. et al. Prevalence of occupational lung disease among Botswana men formerly employed in the South African mining industry. Occup. Environ. Med. 1997; 54:19-26.

21. Osim, E.E., Musabayane, C.T. and Mufunda, J. Lung function of Zimbabwean farm workers exposed to flue curing and attacking tobacco leaves. S. Afr. Med. J. 1998; 88:1127-31

22. Khatami, A, Ponche, J.L., Jabry, E. and Mirabel, P. The air quality management of the region of Great Casablanca (Morocco) Part 1: Atmospheric emission inventory for year 1992. Sci. Total Environ. 1998; 209:201-16.

23. World Health Organisation. World Health Day 1980. Smoking or health, the choice is yours. Wld. Hlth. Org. Chron. 1980; 34:127-130.

24. World Health Organisation. Tobacco: its role in the economy and the health of African countries. Wld. Hlth. Org. Chron. 1985; 39:104-106

25. Yach, D. Tobacco or Health. Tobacco in Africa World Health Forum 1996; 17:29-36.

26. Anyanwu, C.H. and Udekwu, F.A.O. Clinical aspects of pulmonary and pleural carcinoma in Nigeria. Med. J. Zambia 1980; 14:83-89.

27. Ehrlich, R.I., Du Toit, D. Jordan, E. et al. Risk factors for childhood asthma and wheezing. Importance of maternal and household smoking. Amer. J. Respir. Crit. Care Med. 1996; 154:681-8

28. Reddy, P., Meyer-Weitz, A. and Yach, D. Smoking status, knowledge of health effects and attitudes towards tobacco control in South Africa. S. Afr. Med. J. 1996; 80:1389-93.
29. Richards, G.A., Terblanche, A.P., Theron, A.J. et al. Health effects of passive smoking on adolescent children. S. Afr. Med. J. 1996; 86:143-7.

30. Ball, K. Peripheral vascular disease and cigarette smoking. Postgraduate Doctor ( Africa). 1992; 14:55-57.

31. Femi-Pearse, D. Adeniy-Jones, A. and Oke, A.B. Respiratory symptoms and their relationship to cigarette smoking, dusty occupations, and domestic air pollution; Studies in a random sample of an urban African population West Afr. Med. J. 1973; 12:57-63.

32. Sofoluwe, G.O. Smoke pollution in dwellings of infants with bronchopneumonia.Arch. Environ. Hlth 1968;16:670672.

33. Tanimowo, M.O. The respiratory effects of air pollution resulting from sugar production in Bacita, Kwara State Nigeria. Thesis of the Fellowship of the National Postgraduate Medical College of Nigeria. (Internal Medicine) (FMCP), November 1989.

34. Tumwesigire, S.G. and Barton, T. Environmental risk factors for acute respiratory infections among children of military personnel in Uganda. East Afr. Med. J. 1995; 72:290-4

35. Ellegard, A. Cooking fuel smoke and respiratory symptoms among women in low income areas in Maputo. Environ. Hlth Perspect. 1996; 104:980-5.

36. Terblanche, A.P., Nel, C.M., Opperman, L. and Nyikes H. Exposure to air pollution from transitional household fuels in a South African population. J. Expo. Anal. Environ. Epidemiol. 1993; 1:15-22.

37. Ogunsola, O.J. Oluwole, A.F., Asubiojo, O.I. et al Environmental impact of vehicular traffic in Nigeria; health aspects. Sci. Total Environ. 1994; 147:111-6.

38. Chaulet P. After health sector reform, whither lung health? Int. J. Tuberc. Lung. Dis. 1998; 2:349-59.

39. World Health Organisation. Health effects of combined exposures in the work environment. Wld. Hlth. Org. Techn. Rep. Ser. 1981; 662.

40. World Health Organisation. Monitoring global air pollution. Wld. Hlth. Org. Chron. 1978; 32:373-376.

41. Ferry, L.H., Grissino, L.M. and Runfola. P.S. Tobacco dependence curricula in US undergraduate medical education. J. Amer. Med. Ass. 1999; 282: 825-829.

42. Tanimowo, M.O. Respiratory disease among Nigerians working in a sugar industry. East Afr. Med. J. 1996;73:556559.

43. Tanimowo, M.O. Air pollution and the human lung: Pathogenetic aspects and current status in Nigeria.Medicine Today. 1993; 3:18-19. 